\title{
DEGENERATED SOFT TISSUE LESION RESEMBLING A CHONDROMA
}

Alba Thomas ${ }^{1}$, Senthil Kumar², P. Viswanathan ${ }^{3}$, Mohamed Asif ${ }^{4}$

\section{HOW TO CITE THIS ARTICLE:}

Alba Thomas, Senthil Kumar, P. Viswanathan, Mohamed Asif. "Degenerated Soft Tissue Lesion Resembling a Chondroma". Journal of Evolution of Medical and Dental Sciences 2014; Vol. 3, Issue 34, August 11;

Page: 9086-9089, DOI: 10.14260/jemds/2014/3172

ABSTRACT: A 42 year old male fisherman presented with a tender mass in the right side groin/root of the thigh. The entire episode followed a trauma. A biopsy specimen revealed a chondroma like lesion with necrosis. The final diagnosis made was Necrosis of Tendon.

KEYWORDS: Chondroma like lesion, Psuedochondroma.

INTRODUCTION: Chondromas, composed of hyaline cartilage are the second most common cartilage tumor of bone. They may occur in a medullary location (Enchondroma) or on the surface of the bone (Periosteal chondroma) ${ }^{1}$

CASE HISTORY: A 42 year old male came with difficulty in walking and pain aggravated during forward flexion and on attempt to sit on the ground. On examination, tender mass was present at the root of the thigh in the groin region. Clinical diagnosis of an abscess was made. MRI finding revealed Quadriceps Tendon Rupture. Under short GA, the skin was incised, which revealed a hemorrhagic mass. The mass was resected and debridement done; subsequently studied histologically

MACROSCOPIC FINDINGS: Container had multiple gray, black gelatinous mass partly firm in consistency, largest measuring $3.5 \times 2.5 \times 0.5 \mathrm{~cm}$ and the smallest measuring $0.5 \times 0.5 \mathrm{~cm}$. Cut section - solid gray, white slimy areas along with gray, black areas are observed.

MICROSCOPIC FINDINGS: Chondrocytes seen as clusters against the background of hyaline cartilage matrix and myxoid degeneration. The cell clusters are distributed irregularly and areas of hemorrhagic necrosis present.

DISCUSSION: The patient had a similar episode five years back on the other side of the groin which was excised. A fisherman by occupation, he used to push cataraman and boats on sand and in the water front who can get hurt which is often ignored. The lesion histologically appeared like chondroma/well differentiated chondro sarcoma. But on learning the clinical history, a final diagnosis of Traumatic Necrosis of Tendon was made.

NOTE: The patient is well after one year follow up.

Extra skeletal chondroma, a benign cartilaginous tumour that occurs predominantly in hands and feet, has a benign clinical course. ${ }^{2}$ Its predominant single site is fingers, where more than $80 \%$ of extra skeletal chondroma are found. Rare cases have been described in the dura, ${ }^{3,4}$ larynx, ${ }^{5,6}$ pharynx, ${ }^{7}$ oral cavity ${ }^{8,9}$ and skin. ${ }^{10}$ It is often associated with tendons, tendon sheath or joint capsule ${ }^{11}$; unlike periosteal chondroma, it is located outside the periosteum. ${ }^{12,13}$ 
Extra skeletal chondroma usually manifest as slowly enlarging nodule. Tumour mainly affects adults 30 to 60 years of age and is rare in children.14,15

Excised chondromas are usually well demarcated and are firm on palpation. Nearly all are small, seldom exceeding $3 \mathrm{~cm}$ in greatest diameter. They may be attached to a tendon or tendon sheath.

Microscopically, they vary considerably in appearance. About two thirds consist of mature hyaline cartilage arranged in more or less distinct lobular pattern. Some of these tumors are altered by focal fibrosis (Fibrochondroma) or ossification (Osteo chondroma). ${ }^{16}$

Others show myxoid change (Myxo chondroma). About one third display focal or diffuse calcification. Calcification tends to be more pronounced in centre than at periphery of the tumour lobules.That could be granuloma like proliferation of epitheliod and multi nucleated giant cells. This proliferation is most conspicuous at the tumour margin and inter lobular vascular channels. ${ }^{17}$

DIFFERENTIAL DIAGNOSIS: Parachordoma and Myxoid chondrosarcoma can be considered. The possibility of Parachordoma is ruled out due to the absence of physaliferous bodies. Myxoid Chondrosarcoma also called chordoid sarcoma occurs in soft tissue, appears microscopically as stellate or round cell with moderate amount of cytoplasm distributed in cores, strands, nests within myxoid or chondroid background. No benign cartilage will be seen in it.

\section{REFERENCES:}

1. Milgram J W. The origins of osteochondromas and enchondromas. A histopathologic study. Clin Orthop 174:264-284, 1983

2. Dahlin C, Salvador H. Cartilaginous tumours of the soft tissues of the hands and feet. Mayo Clin Proc, 1974,49: 721

3. Brownlee RD, Sevick RJ, Rewcastle ND, et al. Intracranial chondroma. Am J Neuroradiol 18: 889, 1997

4. Takano M, Oka H, Kawano N, et al. Dural chondroma with fat tissue. Acta Neurochir(Wien) 139: 690,1997

5. Lewis JE, Olsen KD, Inwards CY. Cartilaginous tumours of the larynx: clinicopathologic review of 47 cases. Ann Otol Rhinol Laryngol 106: 94, 1997

6. Devaney KO, Ferlito A, Silver CE. Cartilaginous tumours of the larynx. Ann Otol Rhinol Laryngol 104: 251, 1995

7. Wang BH, Guan XL, Xiao LF, et al. Soft tissue chondroma of the parapharyngeal space: a case report. J Laryngol Otol 112: 294, 1998

8. Blum MR, Danford M, Speight PM. Soft tissue chondroma of the cheek. J Orol Pathol Med 22: 334,1993

9. Tosios K, Laskaris G, Eveson J, et al. Benign cartilaginous tumour of the gingiva: a case report. Int J Oral Maxillofac Surg 22: 231, 1993

10. Ando K, Goto Y, Hirabayashi N, et al. Cutaneous cartilaginous tumour. Dermatol Surg 21: 339, 1995

11. Bansal M, Goldman AB, DiCarlo EF, et al. Soft tissue chondromas: diagnosis and differential diagnosis. Skeletal Radiol 22: 309, 1993 


\section{CASE REPORT}

12. Nguyen TP, Burk DL Jr. Musculoskeletal case of the day: periosteal (juxtacortical) chondroma. AJR 165: 203, 1995

13. Mandahl N, Hein S, Arheden K, et al. Chromosomal rearrangements in chondromatous tumours. Cancer 65: 242, 1990

14. Kamysz JW, Zawin JK, Gonzalez-Crussi F. Soft tissue chondroma of the neck: a case report and review of literature. Pediatr Radiol 26: 145, 1996

15. Pollock L, Malone M, Shaw DG. Childhood soft tissue chondroma: a case report. Pediatr Pathol Lab Med 15: 437, 1995

16. Reith JD, Bauer TW, Joyce MJ. Paraarticular osteochondroma of the knee: a report of two cases and review of literature. Clin Orthop 334: 225, 1997

17. Yamada T, Irisa T, Nakano S, et al. Extraskeletal chondroma with chondroblastic and granuloma like elements. Clin Orthop 315: 257, 1995

\section{MICROSCOPC PICTURES}

Fig. 1 \& Fig. 2: Chondrocytes along with degenerated fibro collagenous tissue.

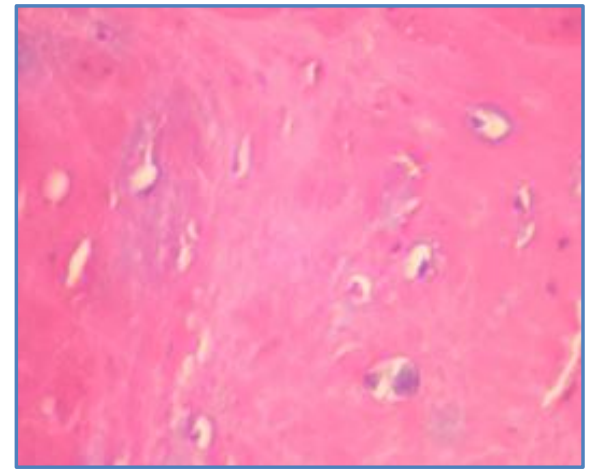

Fig. 1: H \& E STAINING 10X



Fig. 2: H \& E STAINING 20X

Fig. 3 \& Fig. 4: Mature hyaline cartilage with areas of necrosis.



Fig. 3: H \& E STAINING 10X

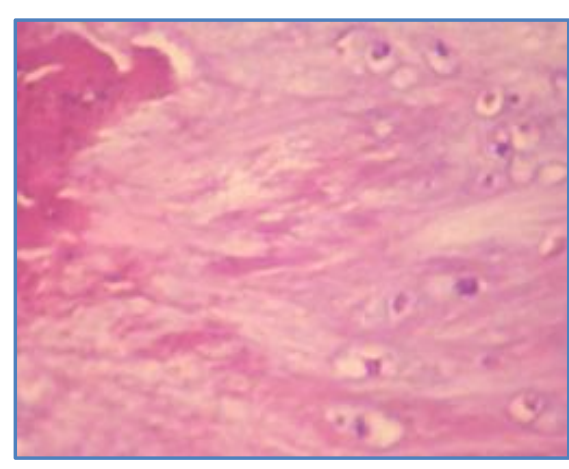

Fig. 4: H \& E STAINING 20X 


\section{CASE REPORT}

Fig. 5: Benign collection of lacunar cells in an area of necrosis.



Fig. 5: H \& E STAINING $20 \mathrm{X}$

\section{All the microscopic pictures were taken using:}

Nikon Coolpix Model 8400

$\mathrm{X}$ - Indicates the power of objective

Stain used is Haemotoxylin and Eosin

\section{AUTHORS:}

1. Alba Thomas

2. Senthil Kumar

3. P. Viswanathan

4. Mohamed Asif

\section{PARTICULARS OF CONTRIBUTORS:}

1. $3^{\text {rd }}$ Year Post Graduate, Department of Pathology, Rajah Muthiah Medical College, Annamalai University.

2. $3^{\text {rd }}$ Year Post Graduate, Department of Pathology, Rajah Muthiah Medical College, Annamalai University.

3. Professor, Department of Pathology, Rajah Muthiah Medical College, Annamalai University.

4. Consultant, Department of Orthopaedics, Chidambaram.

\section{NAME ADDRESS EMAIL ID OF THE} CORRESPONDING AUTHOR:

Dr. P. Viswanathan,

Professor,

Department of Pathology,

Faculty of Medicine,

Rajah Muthiah Medical College,

Annamalai University,

Chidambaram-608002,

Tamilnadu, India.

Email: drpviswanathan2013@gmail.com

Date of Submission: 16/07/2014.

Date of Peer Review: 17/07/2014.

Date of Acceptance: 04/08/2014.

Date of Publishing: 11/08/2014. 